\title{
Pilot scale study on characterization and performance of aerobic granular sludge to treat domestic wastewater
}

\author{
Hazlami Fikri Basri a, b, ${ }^{,}$, Aznah Nor Anuar a, b, ${ }^{,}$, Mohd Hakim Ab Halim a, b, \\ a Department of Environmental Engineering and Green Technology, Malaysia-Japan International Institute of Technology (MJIIT), Universiti \\ Teknologi Malaysia, 54100 Jalan Sultan Yahya Petra, Kuala Lumpur, Malaysia \\ b Disaster Preparedness and Prevention Centre, Malaysia-Japan International Institute of Technology (MJIIT), Universiti Teknologi Malaysia, 54100 \\ Jalan Sultan Yahya Petra, Kuala Lumpur, Malaysia \\ *Corresponding author: hazlamibasri@gmail.com, aznah@utm.my, mohdhakim@utm.my
}

\section{Article history}

Received 7 Mac 2019

Revised 5 May 2019

Accepted 18 October 2019

Published Online 2 February 2020

\begin{abstract}
Aerobic granular sludge (AGS) is a wastewater treatment technology that is known for having unique advantages such as great settling ability, high biomass level, good shock resistance, and able to withstand high organic loading rate (OLR) and toxic pollutants. Since studies on AGS development are mostly conducted in laboratory scale, the detailed knowledge regarding the pilot scale study is still limited especially for hot and humid tropical climate condition. Therefore, this study focused on the characteristics and performance of AGS cultivated in a pilot-scale bioreactor for hot and humid tropical climate condition, specifically in Malaysia. The formation of AGS as well as biomass concentration were also investigated during the treatment of real domestic wastewater. From the result, it was found that the highest average diameter of the cultivated mature granules was $3.36 \mathrm{~mm}$ with a biomass concentration of $12.48 \mathrm{~g} \mathrm{~L}^{-1}$ after 93 days of operation. The aerobic granular sludge also achieved promising removal rates of $89 \%, 75 \%, 96 \%$, and $93 \%$ for COD, phosphate, ammoniacal nitrogen, and total inorganic nitrogen, respectively.
\end{abstract}

Keywords: Aerobic granular sludge, reactor, domestic wastewater, hot and humid tropical climatic condition, pilot scale

(C) 2020 Penerbit UTM Press. All rights reserved classified into biological, chemical, and physical processes. Among them, biological treatment is considered as the most sustainable approach for the elimination of nutrients and organics. It is proven to be a great shield against the wastewater pollutant such as ammonia nitrogen $\left(\mathrm{NH}_{3}-\mathrm{N}\right)$, nitrogen $(\mathrm{N})$, and chemical oxygen demand $(\mathrm{COD})$ (Ab Halim et al., 2016). Currently, there are many types of biological treatment system for wastewater treatment such as activated sludges, sequencing batch reactor, up-flow anaerobic sludge blanket reactors, and constructed wetlands.

New biological treatment technologies called aerobic granular sludge (AGS) has emerged as an excellent prospect for industrial and municipal wastewater treatment (Henriet et al., 2016). AGS is a spherical compact sludge formed through self-immobilization of microorganisms and floc under the aerobic or anaerobic environment (Sarma and Tay, 2018). Importantly, it is recognized for having unique advantages such as great settleability, good shock resistance, high biomass level, and able to cope high organic loading rate and harmful pollutants (Xia et al., 2018). Besides, AGS was successfully cultivated in sequencing batch reactor (SBR) which produces less excess sludge and low footprint (Ab Halim, 2018). These significant advantages have made AGS to be considered as one of the finest biological treatment technologies.

Normally, most of the research on AGS for the treatment of domestic wastewater was conducted in a laboratory scale with small reactor volume and limited processing capacity. According to Long et al. (2014), research in the laboratory scale only contributed to the theoretical implication of engineering operation and further testing is needed for pilot-scale project. Only several studies on the AGS application with pilot scale projects were discussed in detailed for the past decade (Ni et al., 2009; Liu et al., 2011; Long et al., 2014; Rocktäschel et al., 2015; Hamza et al., 2018). Additionally, in terms of climatic condition, none of the pilot scale studies were focusing on the hot and humid condition where the temperature is more than $18^{\circ} \mathrm{C}$ Hence, this pilot-scale research was conducted to study the characteristic and performance of aerobic granulation for treatment of domestic wastewater in Malaysia's hot and humid tropical climatic condition.

\section{MATERIALS AND METHODS}

\section{Experimental procedures and bioreactor set-up}

A cylindrical column SBR bioreactor (internal diameter of 172 $\mathrm{mm}$ with a total height of $650 \mathrm{~cm}$ ) consisting of a working volume of $15 \mathrm{~L}$ was used in this study (Fig. 1). Then, $7.5 \mathrm{~L}$ (50\% working volume) of activated sludge from the Indahwater Bunus SBR treatment plant was added into the bioreactor during the start-up period as inoculums. A feeding, discharge, and an air pump with the setting time for each phase in the bioreactor was controlled with preprogrammed digital timers. The bioreactor was operated through successive cycles of $3 \mathrm{~h}$. Each cycle consisted of a 60-min influent feeding phase from the bottom of the bioreactor without stirring, 110min aeration phase, 5-min settling period, and 5-min effluent discharge period. Real domestic wastewater was fed into the system 
and discharged by a set of two peristaltic pumps. Furthermore, the bioreactor was aerated with an air pump that was operated at a constant flow rate of $0.7 \mathrm{~m}^{3} \mathrm{~h}^{-1}\left(2.5 \mathrm{cms}^{-1}\right.$ superficial air flow velocity). A fine bubble diffuser located at the bottom of the bioreactor was used for aeration to produce air bubbles. The effluent withdrawal point was positioned at the middle height of the column, operating at volumetric exchange ratio (VER) of $50 \%$ per cycle. The bioreactor was scheduled to run for 93 days without excess sludge discharge, thus the effluent was the only passage for biomass wasting to be transported. The working temperature of the bioreactor was kept at $27 \pm 1{ }^{\circ} \mathrm{C}$ without controlling the dissolved oxygen and $\mathrm{pH}$ level. Fig. 1 shows the schematic diagram of operational reactor setup.

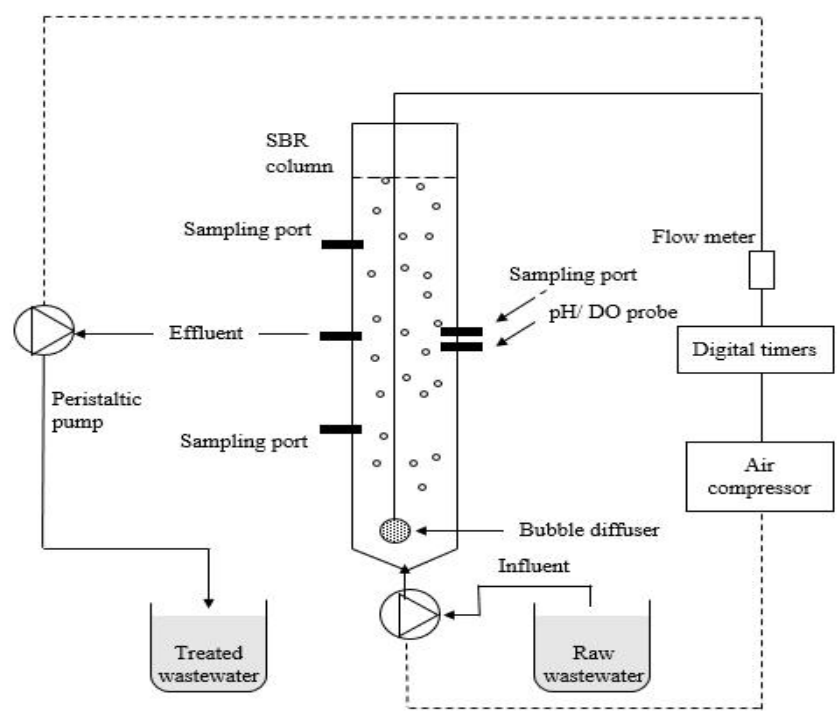

Fig. 1 Schematic diagram of operational reactor setup.

\section{Characteristics of domestic wastewater and seed sludge sampling}

The sample of real domestic wastewater was obtained from Bunus sewage treatment plant, Kuala Lumpur. The raw wastewater sample was collected from the inlet point of the plant before any type of treatment and then sieved with a $1.0 \mathrm{~mm}$ mesh to eliminate large debris and solid materials which can cause clogging to the influent tubes. The collected sample of real domestic wastewater was stored in a cool storage room at $4{ }^{\circ} \mathrm{C}$ temperature until it was fed to the reactor system. The characteristics of the real domestic wastewater used throughout the experiment were presented in Table 1 in comparison with the real domestic wastewater as described in the previous literature by Al-Jlil (2009). The parameter used for real domestic wastewater characteristics were BOD, COD, TN, AN, and TP. The bioreactor was inoculated with fresh activated sludge collected from one of the SBR in Bunus STP. The amount of inoculum was $7.5 \mathrm{~L}$, with a mixed liquor suspended solid (MLSS) concentration of $12.48 \mathrm{~g}$ $\mathrm{L}^{-1}$ and a mixed liquor volatile suspended solid (MLVSS) concentration of $8.96 \mathrm{~g} \mathrm{~L}^{-1}$. The seed sludge was brown in color with fluffy loose structure.

\section{Analytical methods}

Different analytical methods were conducted to determine and measure related parameters throughout the study. Both sludge and water (influent and effluent) were crucial component for this research. Therefore, each of them must be analyzed according to standard procedures. In the case of removal performance, many parameters were taken into consideration. $\mathrm{COD}, \mathrm{NH}_{3}-\mathrm{N}, \mathrm{NO}_{2}{ }^{-}, \mathrm{NO}_{3}{ }^{-}$and $\mathrm{PO}_{4}{ }^{3-}$, and TP were determined using a spectrophotometer (DR 6000, Hach Co., USA). Meanwhile, the measurements of MLSS and MLVSS biomass concentration were carried out according to Standard Methods for the Examination of Water and Wastewater (Rosman et al., 2013). The sludge volume index $\left(\mathrm{SVI}_{5}\right)$ measurement was carried out by the method proposed by de Kreuk et al. (2005). The value of $\mathrm{pH}$ and dissolved oxygen (DO) were monitored regularly using the $\mathrm{pH} / \mathrm{DO}$ meter (Orion 4-Star Benchtop pH/DO Meter). For the characterization of AGS, granules were prepared based on Dahalan et al. (2015) and Liu and Tay (2002). A stereomicroscope equipped with a digital image analyzer (Olympus) was used to observe the morphology and structure of the developed granules. Platinum sputter coating for 60 seconds (Q150R S, Quarum, UK) was conducted for the pre-treatment procedure for SEM image. Scanning electron microscope (SEM) (JSM 7800F, Jeol, Japan) was used to observe the microstructure compositions of the developed granules. Other parameters such as settling velocity (SV) and the granular strength of the granules were also analyzed. The SV was measured by calculating the average time required for a single granule to settle at a certain height in a 1-liter cylinder glass filled with distilled water. On the other hand, the granules strength was determined by applying shear force towards the granules through agitation using an orbital shaker at $200 \mathrm{rpm}$ for $5 \mathrm{~min}$.

\section{RESULTS AND DISCUSSION}

\section{Wastewater characterization}

The wastewater characterization sampling was conducted in STP Bunus treatment plant. The sample was collected at the inlet point of the plant containing raw wastewater. The experimental work was held at Environmental Engineering Laboratory, MJIIT, UTM, Kuala Lumpur. The wastewater characterization study was performed by measuring several parameters such as $\mathrm{pH}$, Ammoniacal nitrogen $\left(\mathrm{NH}_{3}-\mathrm{N}\right)$, Biochemical Oxygen Demand (BOD), Chemical Oxygen Demand (COD), Phosphate $\left(\mathrm{PO}_{4}{ }^{3-}\right)$, Nitrate $\left(\mathrm{NO}_{3}{ }^{-}\right)$, and Nitrite $\left(\mathrm{NO}_{2}{ }^{-}\right)$. The collected data on wastewater characteristic are shown in Table 1.

Table 1 Characteristics of real domestic wastewater in this study and typical domestic wastewater.

\begin{tabular}{l|ccc}
\hline \multirow{2}{*}{ Parameter } & \multicolumn{3}{|c}{ Real Domestic wastewater } \\
\cline { 2 - 4 } & $\begin{array}{c}\text { (Metcalf \& } \\
\text { Eddy, 2003) }\end{array}$ & (Al-Jlil, 2009) & (this study) \\
\hline $\mathrm{pH}$ & $7 \pm 2$ & $n . S$. & $7.16 \pm 0.06$ \\
COD & 500 & 130 & $206 \pm 200$ \\
BOD & 200 & 129 & $127 \pm 2$ \\
Ammoniacal & 25 & 26.25 & $19.58 \pm 1.37$ \\
Nitrogen & 0 & $n . S$. & $21 \pm 7.95$ \\
Nitrite & 0 & $n . S$. & $37.94 \pm 10.43$ \\
Nitrate & 5 & 1.92 & $7.57 \pm 1.19$ \\
Phosphate & & & \\
\hline
\end{tabular}

\section{Formation mechanism of AGS in SBR and morphology observation}

Fig. 2 shows the transformation of granules morphological characteristic from day 0 to day 90 of bioreactor operation. At the beginning of the experiment, i.e. on day 0 , the fresh activated sludge was observed to have a loose, fluffy, and irregular shape. After a few days, the fluffy-shaped sludge has gradually washed out from the system, leaving good settling sludge to retain and grow. Harun et al. (2014) mentioned that partial washout singles out good settling bacteria which leads to the accumulation of aerobic granules in the reactor. After 30 days of operation, a minority of small granules started to show up with the size ranging from $0.1 \mathrm{~mm}$ to $0.5 \mathrm{~mm}$. The morphology of these initial granules was still in irregular-shaped and non-clear boundary as shown in Fig. $2 \mathrm{~b}$. By the $60^{\text {th }}$ day, the number of small granules has increased significantly and larger granules with regular and non-fluffy shape were observed seen. The bioreactors achieved stable state after approximately 72 days of operation when mature aerobic granules started to appear with a relatively solid and smooth surface. At the end of the experiment, there were a majority of smooth, regular, and solid surface granules with diameters from 2.0 to $2.5 \mathrm{~mm}$ (Fig. 2d) developed in the system. 

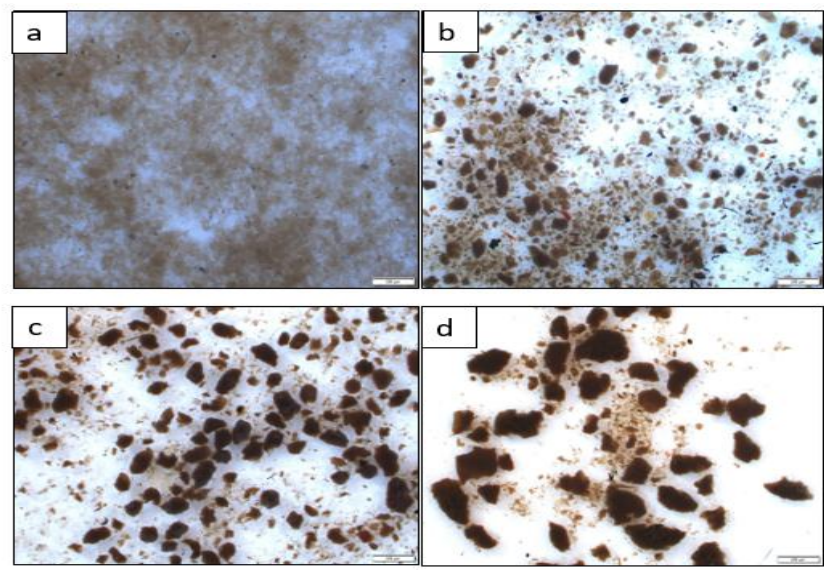

Fig. 2 Transformation of seed sludge for a period of 90 days operations a) Day 0 Seed sludge, b) Day 30, c) Day 60, d) Day 90 : Mature granules (magnification: 8.98x).

The development of AGS was influenced by the ability of the microorganism to interact with one another and the surrounding condition. One of the mechanisms for the interaction was the secretion of extracellular polysaccharide substances (EPS) by the microorganism to protect itself from any threat (Harun et al., 2014). EPS acts as a sticky glue between the microbial cells and strengthen the granules structure during aggregation. In this study, a closer observation by using SEM analysis on the surface of mature granules found a vast amount of coccal-shaped bacteria that are tightly bonded to each other (Fig. 3). The coccoid bacteria are seen to be embedded in a thick EPS matrix which ensures the growth of compact aerobic granular sludge. Sheng et al. (2010) stated that EPS have a significant impact on the physicochemical properties of aerobic granules, including structure, surface charge, adsorption ability, settling properties, flocculation, and dewatering properties.
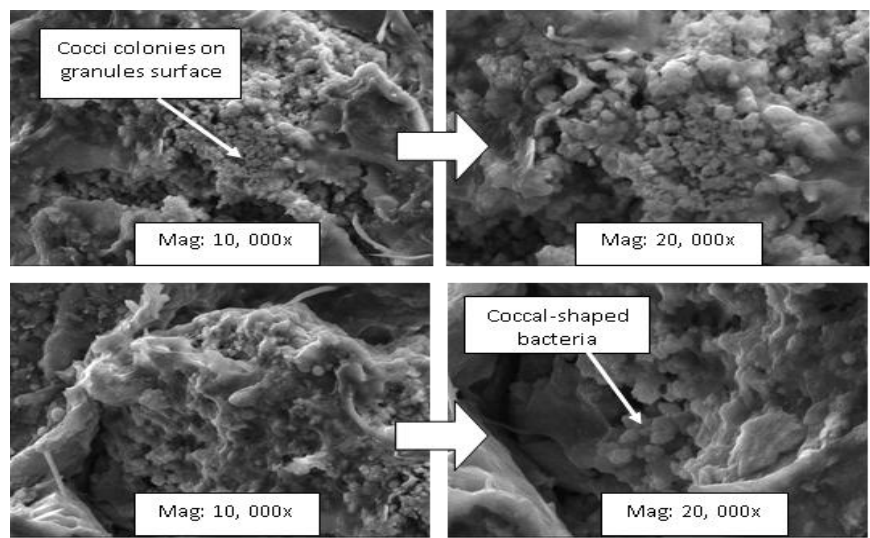

Fig. 3 SEM images of the AGS developed in SBR indicating cocci colonies on granule surface

Additionally, other than EPS, numerous cavities were detected on the aerobic granules surfaces as shown in Fig. 4. According to Song et al. (2009), the cavities act as a passage for the transportation of substrate, oxygen, and nutrients into the inner cores of the granules and ensure the stability within the granules' composition. Moreover, there were also filamentous bacteria as presented in Fig. 5. It was known as the initiator of the biomass aggregation process by forming mycelial pellets which settle very well (Seow et al., 2016). According to Wrinkler et al. (2017), filamentous bacteria commonly act as an architectural backbone to increase the strength of the AGS structure. The main reason why filamentous bacteria appeared in the granules was because of the availability of the organic compounds during the aeration phase.

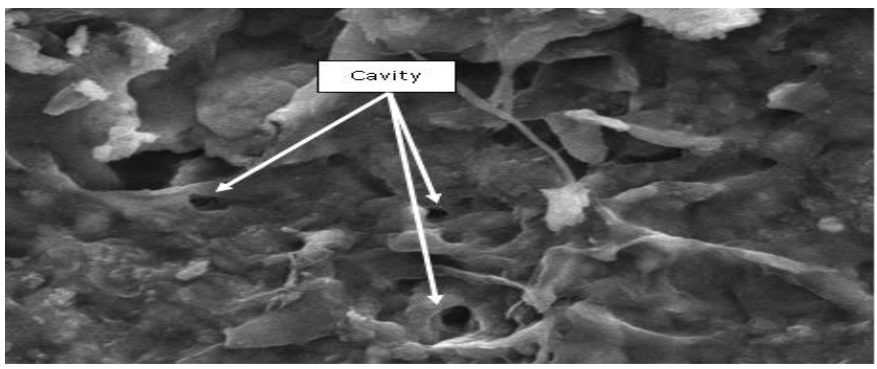

Fig. 4 SEM images of the AGS developed showing cavities on the aerobic granules.
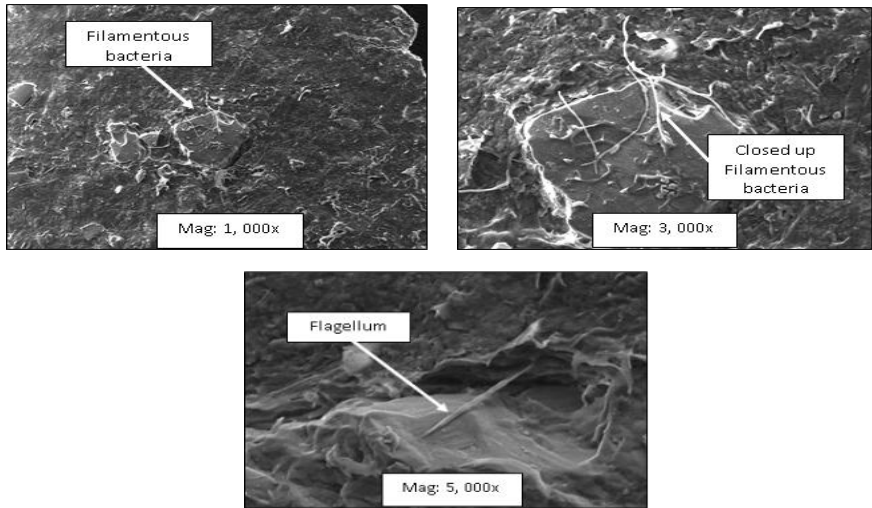

Fig. 5 SEM images of the aerobic granular sludge developed in SBR displaying the flagellum of filamentous bacteria.

\section{Development of biomass in the bioreactor system}

Fig. 6 shows the MLSS and MLVSS profiles for the period of 93 days of the experiment. The MLSS graph in Fig. 6 demonstrates descending MLSS value for the first 18 days. The MLSS was gradually increased until day 30 with $9.34 \mathrm{~g} / \mathrm{L}$. Then, it began to fluctuate for the following 24 days and rose again to achieve the maximum value of $12.48 \mathrm{~g} / \mathrm{L}$ on the $78^{\text {th }}$ day. The MLSS maintained above $12 \mathrm{~g} / \mathrm{L}$ towards the end of the bioreactor operation. Yang et al. (2015) mentioned that a large number of microorganisms could enhance the development of aerobic granules from biomass in the bioreactor. Therefore, the biomass was preserved in the bioreactor to ensure the satisfying performance of the SBR system.

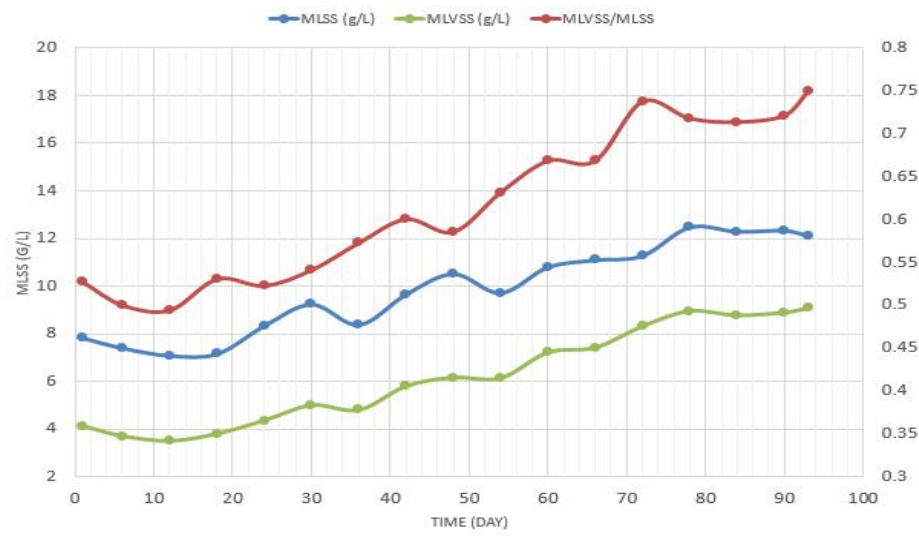

Fig. 6 Biomass development of MLSS and MLVSS.

Meanwhile, Fig. 6 also reveals that MLVSS has the corresponding trend to MLSS. The overall MLVSS values display increasing trend along the experiment starting from day 12 until day 93. The maximum MLVSS value was 8.96 at day 78. According to Long et al. (2016), MLVSS is the organic solid part of MLSS and the optimum ratio of MLVSS/MLSS is 0.8 . At the $78^{\text {th }}$ day, the MLVSS/MLSS ratio was 0.72 showing a good sign of specific quantity or biomass inside the bioreactor system. 


\section{Settling velocity and granular strength of aerobic granular sludge}

Fig. 7 illustrates the settling velocity profiles of the AGS from day 0 to day 93 . The settling velocity analysis resulted in the AGS settled at rates of $8.44 \mathrm{~m} \mathrm{~h}^{-1}$ to $72.33 \mathrm{~m} \mathrm{~h}^{-1}$ with an average value of $40.4 \mathrm{~m}$ $\mathrm{h}^{-1}$. At the beginning of the operation, the sludge settling velocity was $8.44 \mathrm{~m} \mathrm{~h}^{-1}$. It was categorized in typical settling velocity of floc (7 to $10 \mathrm{~m} \mathrm{~h}^{-1}$ ) (Othman, 2016). Afterward, the settling velocity steadily increases as the operation time increases. The biomass concentration also increases, proving the granules were becoming denser and compact in structure. This condition was supported by Muda (2010) stating that the rise on the settling velocity of granules has a strong influence on the biomass concentration inside the reactor.

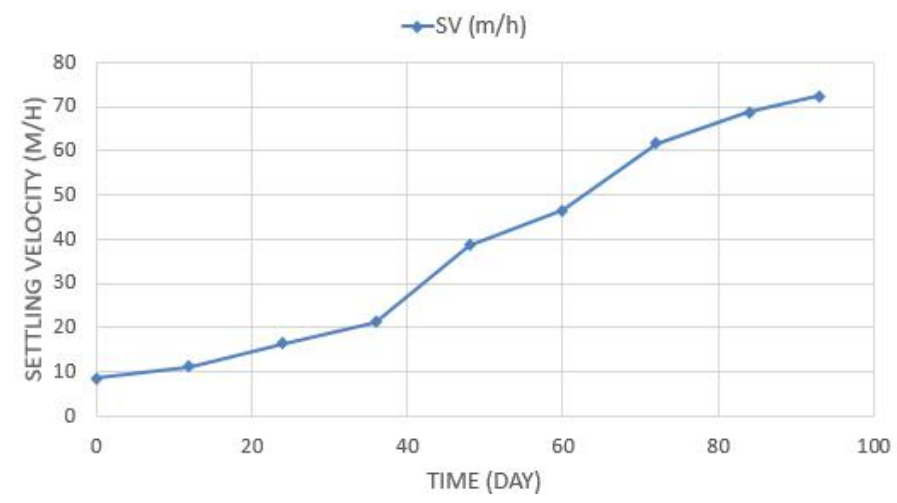

Fig. 7 Settling velocity of aerobic granules cultivated in the SBR.

In term of AGS strength, it was measured by using integrity coefficient (IC). Smaller IC value signifies a higher strength of aerobic granules and vice versa. IC value is related to the granules capability to retain as high structural integrity granules during high shear force in SBR aeration phase. The IC values of aerobic granules cultivated along 93 days of this study were recorded in Fig. 8. By referring to the figure, the overall IC values of the granules declined gradually as the granules became matured. The initial IC value was 38 and it reduced to 14 after the experiment. According to Ghangrekar et al. (2005), granules can be considered high strength when the IC values were less than 20 . Therefore, the developed granules can be considered high strength granules.

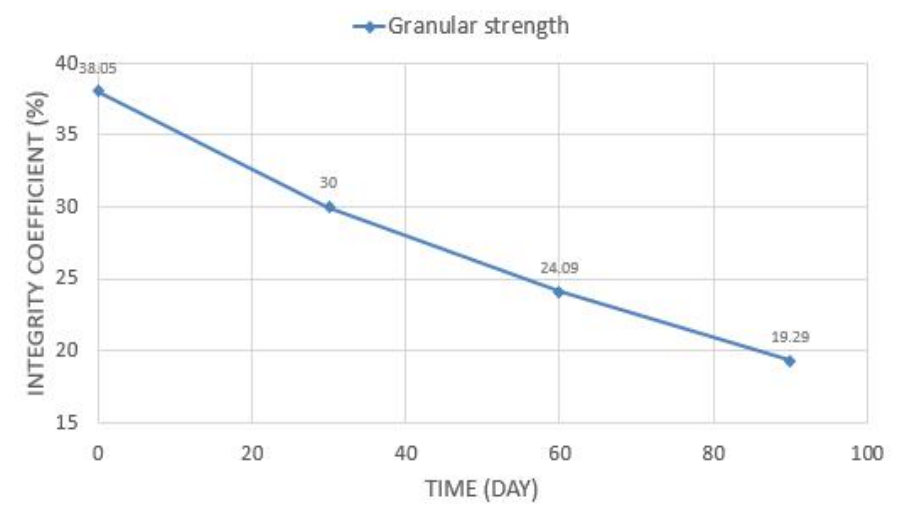

Fig. 8 Strength of aerobic granules cultivated in the SBR.

\section{Removal performance of aerobic granular sludge}

The effluent concentrations of $\mathrm{COD}, \mathrm{PO}_{4}^{2-}, \mathrm{NO}_{3}-\mathrm{N}, \mathrm{NO}_{2}-\mathrm{N}$, and $\mathrm{NH}_{3}-\mathrm{N}$ were consistently monitored during the aerobic granulation process.

\section{Chemical oxygen demand removal}

The concentration and removal of COD throughout 93 days of operation are shown in Fig. 9. In the early 10 days of bioreactor operation, the COD removal rate decreased from $54.6 \%$ to $46.2 \%$. This was due to partial washout of sludge in the bioreactor thus slowing down the microorganism growth rate. After that, the COD removal performance increase gradually until the $33^{\text {rd }}$ day reaching
$78.4 \%$. As the experiment continued, the COD performance fluctuated for the next 33 days starting from day 33 to day 66 because of the fluctuation of influent COD concentration. Moreover, the removal percentage also has gone up and down due to the physicochemical adaptation of microbial community growth in the system (Abdullah et al., 2013). Then, the COD performance become stable starting from day 69 continuously towards the end of the experiment showing the maturity stage of the granules. It stabilizes in the range of $83.1 \%$ to $89.4 \%$ with the highest COD removal performance was $89.4 \%$ on day 81 .

COD

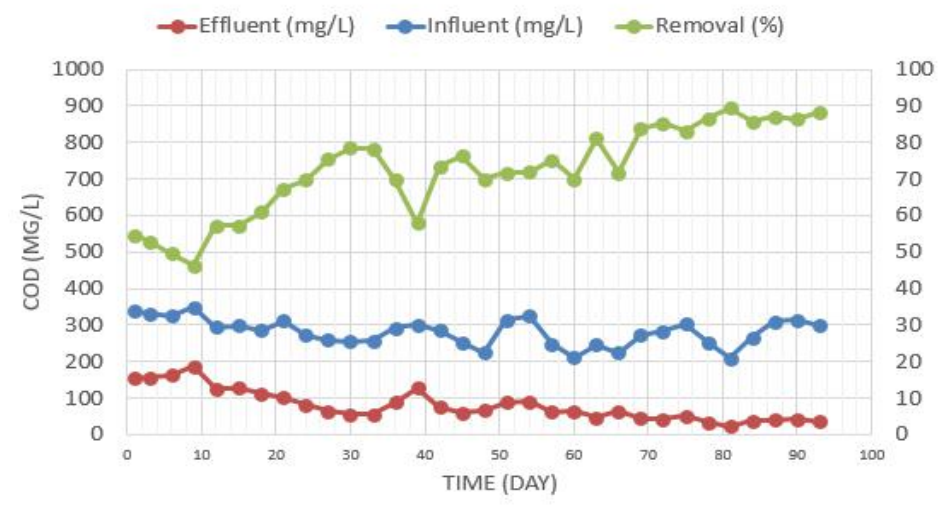

Fig. 9 Removal performance of COD.

\section{Phosphorus removal}

The removal performance of phosphate is presented in Fig. 10 The phosphate removal performance was fluctuating almost throughout the experiment. Since the SBR operation mode involved passive influent feeding, aerobic process for biological reaction, settling phase and effluent discharge, the growth of microbes in the bioreactor was subject to occasional fluctuations. However, the overall trend of phosphate removal performance increased as experiment progressed. The influent of phosphate concentration was between $9.45 \mathrm{mg} / \mathrm{L}$ and $22.4 \mathrm{mg} / \mathrm{L}$ while the effluent concentration was approximately $3.43 \mathrm{mg} / \mathrm{L}$ to $13.47 \mathrm{mg} / \mathrm{L}$. The highest phosphate removal achieved was $75.6 \%$ on day 84 while the lowest was $5.5 \%$ on day 1. The low performance was probably due to the small quantity of polyphosphate-accumulating organisms (PAO) that significantly influence the passive bioactivity of related organisms in the bioreactor (Nancharaiah et al., 2017). Nonetheless, the phosphate removal performance in this study is comparable to Song et al. (2009) who studied AGS performance at $25-35{ }^{\circ} \mathrm{C}$ which is a similar case with tropical climate temperature.

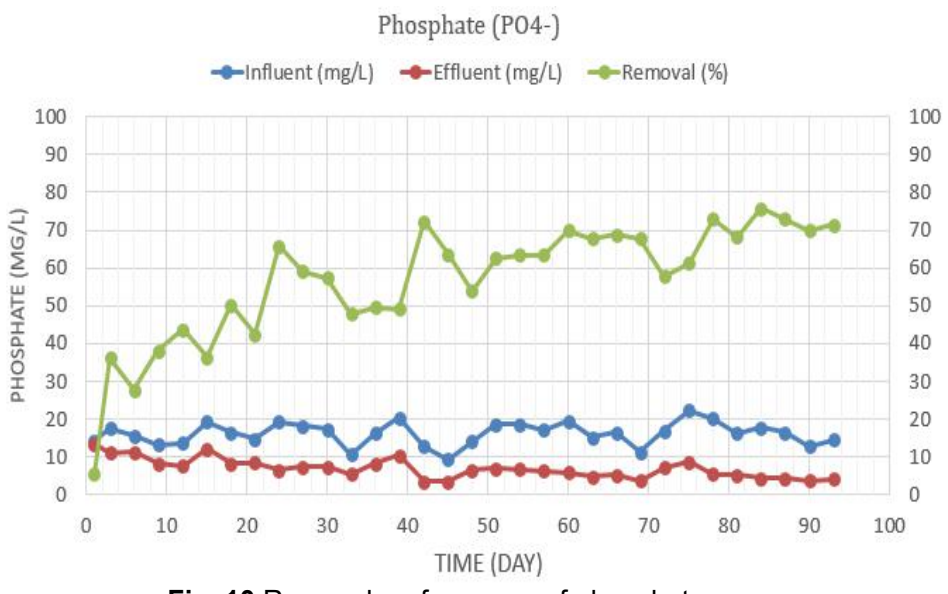

Fig. 10 Removal performance of phosphate.

\section{Nitrogen removal}

The first element of nitrogen compound is $\mathrm{NH}_{3}-\mathrm{N}$ which often presents in domestic wastewater. Based on Fig. 11, the trend for ammonia removal performance is quite similar with COD removal performance. However, the removal performance of $\mathrm{NH}_{3}-\mathrm{N}$ was far greater than COD and other parameters with the highest removal 
percentage of $95.8 \%$. In the first 10 days of the experiment, the $\mathrm{NH}_{3}$ $\mathrm{N}$ removal performance was slightly dropped and performed below 75 $\%$. After that, the performance gradually increased and fluctuated for the next 44 days. The removal rate was maintained above $80 \%$ starting from day 39 and it increased along with the formation of AGS $\mathrm{Ab}$ Halim et al. (2016) reported that the formation of granules could encourage the production of nitrifying bacteria. This circumstance leads to the enhancement of the nitrification process of the AGS which is the case for this study. As proved, the removal percentage becomes stable starting from day 54 towards the end of the experiment with an average of $93.4 \%$. Overall, the effluent concentration of $\mathrm{NH}_{3}-\mathrm{N}$ obtained was below $10 \mathrm{mg} / \mathrm{L}$, and the lowest concentration was during day 90 with $0.8 \mathrm{mg} / \mathrm{L}$.

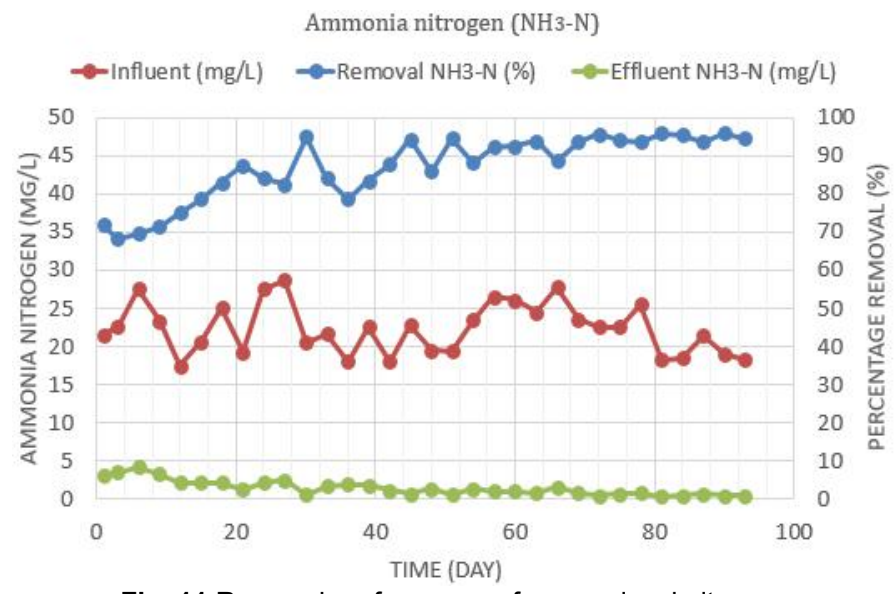

Fig. 11 Removal performance of ammoniacal nitrogen.

Meanwhile, total inorganic nitrogen (TIN) is also one of the parameters being analyzed in the scope of AGS removal performance. TIN is the sum of three nitrogen elements that are $\mathrm{NO}_{3}^{-}-\mathrm{N}, \mathrm{NO}_{2}{ }^{-} \mathrm{N}$, and $\mathrm{NH}_{3}-\mathrm{N}$.

Fig. 12 shows the removal performance of TIN and the effluent of $\mathrm{NO}_{3}{ }^{-}-\mathrm{N}, \mathrm{NO}_{2}{ }^{-} \mathrm{N}$, and $\mathrm{NH}_{3}-\mathrm{N}$ from the beginning of the experiment towards the end of the aerobic granules' development period. Based on the figure, the removal performance of TIN fluctuated in the former 60 days of the experiment, and afterward, the concentration constantly decreased and become stable on day 69 onwards. The stable condition proved that AGS maturation leads to a better removal performance of nitrogen on the last 20 days of operation with the average percentage of $91 \%$. The effluent concentration of TIN was fluctuated for most of the time but slowly decreased due to the influent concentration along with the maturation of AGS during the last 30 days of the experiment. At the same time, $\mathrm{NO}_{3}^{-}-\mathrm{N}, \mathrm{NO}_{2}{ }^{-} \mathrm{N}$, and $\mathrm{NH}_{3}-\mathrm{N}$ are also having a significant reduction of effluent concentration at the end of the experiment.

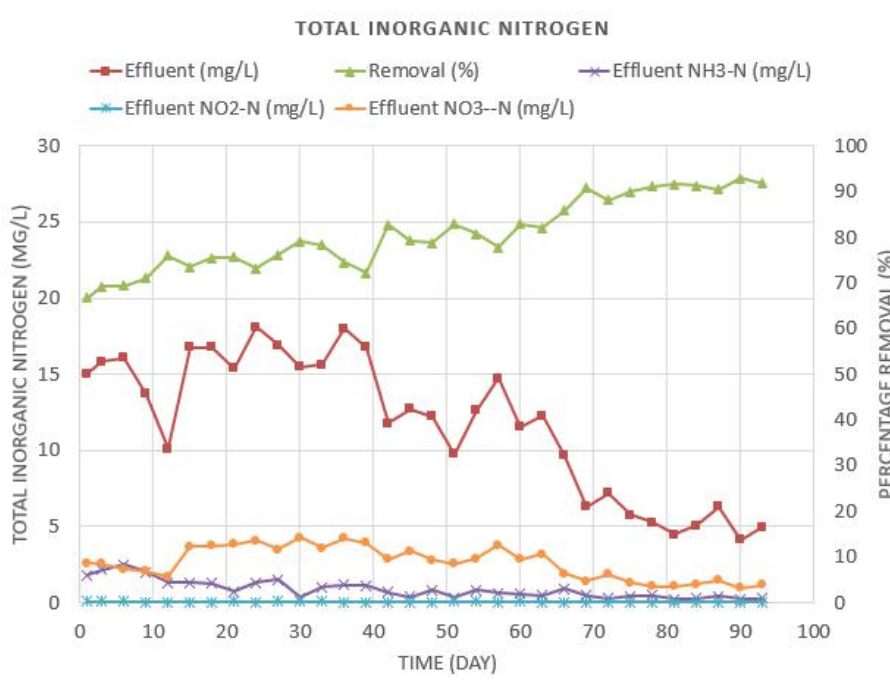

Fig. 12 Removal performance of total inorganic nitrogen.
The outcome of this research suggests that the maturation of AGS provides a conducive atmosphere for the enrichment of facultative bacteria and anaerobic bacteria, which contribute to a simultaneous nitrification and denitrification process. Therefore, the excellent biological activity of the microbes in the bioreactor could be achieved in the long run during the nitrification process of this study.

\section{CONCLUSION}

In conclusion, the aerobic granular sludge was successfully developed in a pilot-scale bioreactor fed with real domestic wastewater at temperature $24{ }^{\circ} \mathrm{C}$ to $27{ }^{\circ} \mathrm{C}$, which represent hot and humid tropical climate condition. AGS with the highest average diameter of $3.36 \mathrm{~mm}$ was cultivated and possessed good strength and stability with a $19.29 \%$ integrity coefficient (IC) value. Meanwhile, the AGS also have an excellent removal rate of ammonia nitrogen with $96 \%$ followed by total inorganic nitrogen (93\%), COD (89\%), and phosphorus (40\%). Therefore, the results from this pilot-scale study are useful to the full-scale application of the AGS technology in hot and humid tropical climate condition in the near future.

\section{ACKNOWLEDGEMENT}

The authors wished to thank the Ministry of Education Malaysia (Higher Education) and Universiti Teknologi Malaysia for the financial support of this prototype development research grant scheme (Grant No: R.K 130000.7843.4L682). The first author also would like to express his gratitude to the Malaysia-Japan International Institute of Technology for the scholarship granted.

\section{REFERENCES}

Ab Halim, M. H., Anuar, A. N., Jamal, N. S. A., Azmi, S. I., Ujang, Z., Bob, M. M. (2016). Influence of high temperature on the performance of aerobic granular sludge in the biological treatment of wastewater. Journal of Environmental Management, 184, 271-280.

Ab Halim, M. H. (2018). Development of aerobic granules in sequencing batch reactor system for treating high-temperature domestic wastewater ( $\mathrm{PhD}$ thesis). Universiti Teknologi Malaysia, Skudai.

Abdullah, N., Yuzir, A., Curtis, T. P., Yahya, A., Ujang, Z. (2013) Characterization of aerobic granular sludge treating high strength agrobased wastewater at different volumetric loadings. Bioresource Technology, 127, 181-187.

Al-Jiil, S. A. (2009). COD and BOD reduction of domestic wastewater using activated sludge, sand filters and activated carbon in Saudi Arabia. Biotechnology, 8(4), 473-477.

Dahalan, F. A., Abdullah, N., Yuzir, A., Olsson, G., Hamdzah, M., Din, M. F. M., Ahmad, S. A., Khalil, K. A., Anuar, A. N., Noor, Z. Z., Ujang, Z. (2015). A proposed aerobic granules size development scheme for aerobic granulation process. Bioresource Technology, 181, 291-296.

de Kreuk, M. K., Pronk, M., van Loosdrecht, M. C. M. (2005). Formation of aerobic granules and conversion processes in an aerobic granular sludge reactor at moderate and low temperatures. Water Research, 39(18), 44764484

Ghangrekar, M. M., Asolekar, S. R., Joshi, S. G. (2005). Characteristics of sludge developed under different loading conditions during UASB reactor start-up and granulation. Water Research, 39(6), 1123-1133.

Hamza, R. A., Iorhemen, O. T., Zaghloul, M. S., Tay, J. H. (2018). Rapid formation and characterization of aerobic granules in pilot-scale sequential batch reactor for high-strength organic wastewater treatment. Journal of Water Process Engineering, 22, 27-33.

Harun, H., Nor-Anuar, A. (2014). Development and utilization of aerobic granules for soy sauce wastewater treatment: optimization by response surface methodology. Jurnal Teknologi, 69(5), 32-33.

Henriet, O., Meunier, C., Henry, P., Mahillon, J. (2016). Improving phosphorus removal in aerobic granular sludge processes through selective microbial management. Bioresource Technology, 211, 298-306.

Liu, Y. Q., Kong, Y., Tay, J. H., Zhu, J. (2011). Enhancement of start-up of pilot-scale granular SBR fed with real wastewater. Separation and Purification Technology, 82, 190-196.

Liu, Y., Tay, J.-H. (2002). The essential role of hydrodynamic shear force in the formation of biofilm and granular sludge. Water Research, 36(7), 1653-1665. 
Long, B., Yang, C. Z., Pu, W. H., Yang, J. K., Jiang, G. S., Dan, J. F., Li, C. Y., Liu, F. B. (2014). Rapid cultivation of aerobic granular sludge in a pilotscale sequencing batch reactor. Bioresource Technology, 166, 57-63.

Long, B., Yang, C. Z., Pu, W. H., Yang, J. K., Jiang, G. S., Li, C. Y., Liu, F. B., Dan, J. F., Zhang, J., Zhang, L., (2016). Rapid cultivation of aerobic granule for the treatment of solvent recovery raffinate in a bench scale sequencing batch reactor. Separation and Purification Technology, 160, 1 10

Muda, K. (2010). Facultative anaerobic granular sludge for textile dyeing wastewater treatment ( $\mathrm{PhD}$ thesis). Universiti Teknologi Malaysia, Skudai.

Nancharaiah, Y. V., Reddy, G. K. K. (2018). Aerobic granular sludge technology: Mechanisms of granulation and biotechnological applications. Bioresource Technology, 247, 1128-1143.

Ni, B. J., Xie, W. M., Liu, S. G., Yu, H. Q., Wang, Y. Z., Wang, G., Dai, X. L. (2009). Granulation of activated sludge in a pilot-scale sequencing batch reactor for the treatment of low-strength municipal wastewater. Water Research, 43(3), 751-761

Othman, I., Anuar, A. N., Ujang, Z., Rosman, N. H., Harun, H., Chelliapan, S. (2013). Livestock wastewater treatment using aerobic granular sludge. Bioresource Technology, 133, 630-634.

Rocktäschel, T., Klarmann, C., Ochoa, J., Boisson, P., Sørensen, K., Horn, H. (2015). Influence of the granulation grade on the concentration of suspended solids in the effluent of a pilot scale sequencing batch reactor operated with aerobic granular sludge. Separation and Purification Technology, 142, 234-241.

Rosman, N. H., Anuar, A. N., Othman, I., Harun, H., Sulong, M. Z., Elias, S. H., Hassan, M. A. H. M., Chelliapan, S., Ujang, Z., (2013). Cultivation of aerobic granular sludge for rubber wastewater treatment. Bioresource Technology, 129, 620-623.

Sarma, S. J., Tay, J. H. (2018). Aerobic granulation for future wastewater treatment technology: Challenges ahead. Environmental Science: Water Research and Technology, 4(1), 9-15.

Seow, T. W., Lim, C. K., Nor, M. H. M., Mubarak, M. F. M., Lam, C. Y. Yahya, A., Ibrahim, Z. (2016). Review on wastewater treatment technologies. International Journal of Applied Environmental Sciences, 11(1), 111-126.

Sheng, G. P., Yu, H. Q., Li, X. Y. (2010). Extracellular polymeric substances (EPS) of microbial aggregates in biological wastewater treatment systems: A review. Biotechnology Advances, 28(6), 882-894.

Song, Z., Ren, N., Zhang, K., Tong, L. (2009). Influence of temperature on the characteristics of aerobic granulation in sequencing batch airlift reactors. Journal of Environmental Sciences, 21(3), 273-278.

Winkler, M. K. H., Meunier, C., Henriet, O., Mahillon, J., Suárez-Ojeda, M. E. Del Moro, G., De Sanctis, M., Di Iaconi, C., Weissbrodt, D. G., (2018). An integrative review of granular sludge for the biological removal of nutrients and recalcitrant organic matter from wastewater. Chemical Engineering Journal, 336, 489-502.

Xia, J., Ye, L., Ren, H., \& Zhang, X. X. (2018). Microbial community structure and function in aerobic granular sludge. Applied Microbiology and Biotechnology, 102(9), 3967-3979.

Yang, G. F., Feng, L. J., Wang, S. F., Yang, Q., Xu, X. Y., Zhu, L. (2015) Performance and enhanced mechanism of a novel bio-diatomite biofilm pretreatment process treating polluted raw water. Bioresource Technology, $191,271-280$ 